\title{
Performance Measurement and Improvement Method for Leather Footwear Industries
}

\author{
Tomas Cherkos Kassaneh ${ }^{1}$ and Robel Negussie Workalemahu ${ }^{2}$ \\ ${ }^{1}$ Lecturer, Faculty of Mechanical \& Industrial Engineering, Bahir Dar Institute of Technology, Bahir Dar University, \\ Bahir Dar, Ethiopia, tomaspoly@gmail.com. \\ ${ }^{2}$ Lecturer, Faculty of Mechanical \& Industrial Engineering, Bahir Dar Institute of Technology, Bahir Dar University, \\ Bahir Dar, Ethiopia, robelneg@gmail.com (corresponding author).
}

Production Management

Received May 23, 2018; received revision July 10, 2018; accepted July 10, 2018

Available online July 14, 2018

\begin{abstract}
Nowadays, there is strong desire for business enterprises to measure, analyze, evaluate and improve their performance due to an increasing competition from current dynamic business environment. Even though, the Ethiopian Leather Footwear Industry (LFI) has huge potential for boosting the country economy, the overall performance of the sector is unsatisfactory due to factors like poor performance measurement and improvement practices, poor planning and control practices and high manufacturing cost. Most performance measurement and improvement methods used so far are not well designed to learning and rarely consider the personal ambition of employees, which results in insufficient improvement in the organizations' performance. Thus, the aim of this study is to assess and evaluate the current performance management practice of Ethiopian LFIs and eventually forward a better firm level total performance improvement technique. A survey questionnaire is used to collect relevant data from fourteen LFIs. Furthermore, benchmarking to identify performance gaps and objective oriented cause and effect analysis to investigate the root causes of low performing industries have been used. The analyzed data confirmed low performance of the industries is due to poor performance measurement and improvement technique. In addition, most methods adopted by the industries doesn't bring expected change yet due to the limitations with the tools and implementation strategies. As a result, a new method for performance measurement and improvement called "total performance scorecard" along with compatible performance measurement framework and implementation guideline which leads to better performance of the Ethiopian footwear industry has been introduced.
\end{abstract}

Keywords: Performance measurement, total performance scorecard, performance improvement.

\section{Introduction}

In recent days, customers demand a wide variety of good quality products at low price and with fast delivery time. Customers also have more market options and information than ever before. As a result, firms become more concerned about the satisfaction of their customers. This resulted in a high need of business enterprises to measure, analyze and improve performance (Tomas et al., 2017). In order to find more appropriate performance measurement and improvement methods and cope with these significant competitive issues of complex management practices, increasing globalization and product differentiation, dynamic customer need a number of researches have been conducted. Gruenberg (2007) define performance as "the valued productive output of a system in the form of goods and services". Gruenberg (2007) also indicates that the performance of these goods or services is measured in terms of quantity, time, and quality parameters. Measurement is the first step in controlling and improving performance. Decisions can hardly be made in the absence of performance measurement (Askin and Standridge, 1993). As
Gruenberg (2007) stated, performance measurement helps to connect company goals to improvements and to set targets for improvement. Together, these help focus and increase the impact of any improvement initiative.

Due to the fact that the Ethiopian Leather Footwear Industry (LFI) has a huge potential for boosting the country's economy, the government of gives higher priority to this sector (UNIDO, 2005; Embassy of Japan in Ethiopia, 2008; Global Development Solution, 2006; Sonobe et al., 2009). However, its overall performance is unsatisfactory due to various internal and external factors which include: poor performance measurement practice, limitation with inputs, poor production planning and control practices, high manufacturing cost (XYZ Company, 2009; Kassaneh and Havinal, 2017). Most performance measurement and improvement methods are insufficiently prepared to learning and only few consider the personal ambitions of employees, which in turn leads to insufficient change in the organization's performance. Even the existing methods are not suitable, mostly financial based and also face failure in the implementation due to poor implementation strategy or guide. Beyene 
et.al (2018) revealed that Ethiopian textile industry is also suffering from poor performance measurement and improvement methods.

Thus, the aim of this study is to review performance management practice of Ethiopian LFIs by identifying the critical problems, and eventually forward appropriate firm level total performance measurement and improvement method. Specifically, it is to assess the current footwear factories performance management practices, identify the critical factors/ problems, evaluate the available methods and propose firm level total performance measurement and improvement method with its measurement framework and implementation guideline.

\section{Methodology of the Research}

To conduct this study, data is collected through observation, survey questionnaire, interview and discussion with company experts. Moreover, different company records and reports on production and performance are used.

In the first stage of the study, an extensive survey has been conducted to know the existing concepts, arguments, methods and advancements on performance measurement and improvement with a particular focus on the problems and improvement activities of manufacturing industry. Then survey questionnaire has been developed and randomly distributed to fourteen selected Large and Medium LFIs. The objective of the survey questionnaire was to assess the current performance status, existing performance management practices and factors or problems that affect performance of Ethiopian footwear manufacturing. To see the company level performance assessment, a case company was selected, all processes were observed scientifically and recorded data were analyzed. Finally, before and after the development of the proposed method, interview in the form of discussion with selected experts and management persons in the case company and researchers working in the Leather development Institute (LIDI) were conducted. In addition, previous research works in the area and from organizations such as; ministry of trade (MOT), leather industry development institute (LIDI), ministry of industry (MOI) and Ethiopian leather industry association (ELA) are reviewed. Furthermore, benchmarking has also been used to identify performance gaps in the case company. Objective-oriented cause and effect analysis is used also to investigate and analyze the root causes for the unsatisfactory overall performance of the LFI. Taking different factors, comparison of different performance measurement and improvement methods is conducted. The results of the survey, case study and part of the interview and discussion are all included in the previous version of this paper (Kassaneh and Havinal, 2017).

\section{Result and Discussion}

Though the progress of Ethiopian LFI performance is promising, still it is unsatisfactory and it should be supported by the findings from the analysis and results of the data collected in the study. Firstly, when Ethiopian shoe manufacturing industry productivity is compared with other manufacturers, Ethiopian footwear manufacturing requires a significant improvement. As an example if we compare Ethiopian footwear manufacturers with Chinese, 78 minutes are required to produce a pair of shoe uppers in Ethiopia, whereas only 30 minutes is required for Chinese manufacturers to produce one pair of shoe upper (Sutton and Kellow, 2010). Here it can be considered that there may be some difference in technology, work environment and training background of workers. Though the Ethiopian LFI showed somewhat an increasing trend in its export value, actual exports account on average for about 28 percent of planned export value for the last five year export period (Kassaneh, 2011). The result of the survey questionnaire showed that most LFIs are working at lower performance and even far from the designed production capacity. In addition, the survey results indicate that though most firms use different and inconsistent performance measurement and improvement practices, which is not fully applied and terminated without success. Moreover, most LFIs did not incorporate employee learning, innovation and satisfaction in their performance management practices. Almost all factories did not properly defined performance factors, metrics and targets which can be used as major indicators for performance measurement and improvement.

Data collected from the case company and its analysis result supports the above mentioned problem regarding low performance of the footwear industries. Though the case company selected for this study is among the best shoe factories in Ethiopia, it encounters problem in product quality (11\% rework), material utilization which resulted in $15 \%$ of scraps in the cutting section, maintenance (25\% down time), long procurement lead time (3-5months), low inventory turnover ratio (about 1.5), etc. The high rework problem is resulted from both poor quality of raw material (processed leather) and performance of labor in lasting and finishing technologies.

From the objective-oriented cause and effect analysis made, it is found that the leather shoe factories have both internal and external factors that cause for low performance and competitiveness. However, the external problems need participation of different bodiesgovernment, leather sector associations and organizations. Therefore, the focus of this study is to the firm level problems as these problems can be solved by the firm using its own potentials, resources and appropriate method to improve the organizational performance. The intervention areas in one or another way are related with financial, operational, employee satisfaction, quality performance and customer satisfaction problems which are total organizational performance problems. To solve such problems, it is a good idea to use a total performance improvement method which can have a balanced performance measures and management philosophy.

\section{Selection of Method}

In addition to the review made by Brown (2006), most commonly used performance measurement and improvement models and tools have been reviewed in this study. The review incorporated plenty of performance measurement and improvement models such as balanced scorecards (BSC), business process reengineering (BPR), kaizen blitz, performance prism, ISO 9001:2000 quality system, benchmarking, etc. 


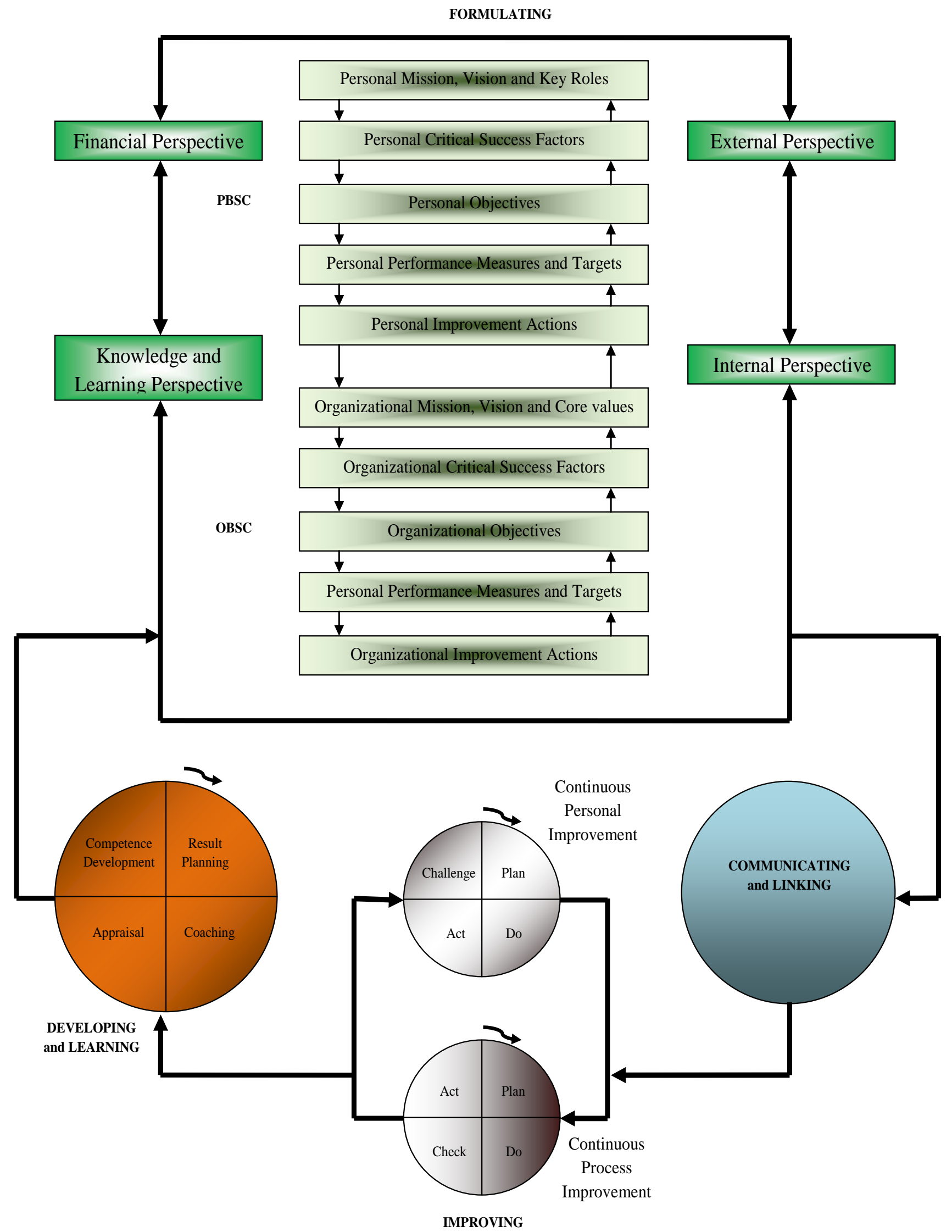

Fig. 1. Proposed performance measurement and improvement method, TPS model (adapted from Rampersad, 2003;

Rampersad, 2005; Rampersad, 2007) 
The review showed that most performance measurement and improvement methods are insufficiently engaged to learning and poor consideration of specific personal ambitions of employees.

Even though, balanced score card, one of the more comprehensive frameworks which has been adopted by many organizations worldwide including USA and Europe (Wongrassamee et al., 2003), it has got many pitfalls and critics by different authors. Rampersad (2005) revealed that the implementation of BSC is disappointing in Europe and South America based on a number of case studies conducted on the subject. Researches indicate scorecards rarely succeed on sustainable financial improvement breakthrough. BSC implementations lack commitment to learning and rarely consider personal ambitions of employees. The researcher doesn't have any arguments on inappropriateness of balanced scorecards as management tools. Rather the researcher support the philosophy of scorecards with some modification, based on organizational balanced scorecards system which has helps to produce better results. The concern here is a need for aligning individual scorecards with organizational scorecards to switch the BSC in to a powerful techniques or sustainable organizational performance (Rampersad, 2007). Accordingly, the researcher founds that Total Performance Scorecard (TPS), which is a recently developed performance improvement philosophy, can solve the gaps observed with the above mentioned methods/models/tools. This model is basically adapted from Rampersad (2003,2005,2007), Madalina (2008), and Brutu (2008) and is a new holistic business management concept which has been developed by expanding and integrating ideas from the conventional performance improvement models. The model shown in Fig. 1 takes the ideas of the Balanced Scorecard to greater heights; it brings individuals, teams, and organizational performance to higher levels by facilitating personal development of employees with its personal balanced scorecard part. As a result, this new method of performance measurement and improvement has been introduced in this study for Ethiopian LFIs.

\section{The Proposed Method}

The proposed method, TPS, focuses on the importance of developing an integrated organizational structure and philosophy by combing the ambitions of employees with that of the company. The development of this structure, which is a melding process, results in individually and organizationally driven corporate culture. In this performance management concept, give solution by keeping and utilizing individual employee rights and capabilities while the organizational structure and philosophy is adjusted to this new environment. TPS, one overall framework has been developed through the expansion and integration of concepts from different management approaches like BSC, TQM, Performance and Competence Management.

The method has basically two main parts; personal balanced scorecards (PBSC) and organizational balanced scorecards (OBSC). The PBSC forms the total of personal vision, mission, critical success factors, key roles, objectives, targets, performance measures and improvement actions [divided along the four perspectives: financial (financial stability), customers (relations with persons around you), internal processes (your physical health and mental state), and knowledge and learning (ability to learn, that is, how to learn learning)]. The development and use of PBSC help to establish the first step in change management. It makes workers to distance themselves from their mindsets and helps them to follow their inner voice. By coaching workers to scrutinize themselves (through a better self-knowledge and selfimage) their learning ability can be improved. . The founder of TPS introduces Plan-Do-Act-Challenge (PDAC) learning cycle, which helps to accomplish a continuous self-learning ability. Whereas, the OBSC is a top-down management technique which helps an organization mission and vision operational in all levels. Here it is necessary to link the corporate units, teams and the individual performance plan of workers to change the strategic vision in to action. In case of the case shoe factory, this is to mean linking the factory's scorecard to the scorecards of each department, divisions and sections, as well as the individual employee performance plans.

According to Madalina (2008), TPS gives a method for maintaining balance between financial and nonfinancial performance indicators and helps to create connection between strategic and operational management. For example, TPS can represent a feasible solution while intending to improve the production management of an organization. In such cases OBSC convert itself to the production scorecard balance system. This includes vision, mission, objectives, critical success factors, improvement targets, performance indicators and actions with in the production system. This concept includes continuous improvement and functional proves control under the production system.

\subsection{Development of Performance Measurement Framework/ Scorecard}

Most existing performance measurement and improvement methods failed in the implementation phase. This is mostly due to the poor strategy followed with relative to the management persons and production workers. Accordingly, in this study a performance measurement framework/scorecard (Table 1 and Table 2) and implementation guideline (Fig. 2) which suits the organizational culture of Ethiopian LFI are developed.

The proposed measurement framework/scorecard is developed based on TPS concept and the key performance indicators (KPIs) of the case company (personal and organizational KPIs) are selected according to the intervention areas identified from the case study analysis and discussion made with experts. Accordingly, the personal scorecard (personal performance measurement framework) contains the four performance perspectives, personal goals of each perspective, personal objectives and performance indicators of the goal, measures to each KPIs and the format for personal performance targets and improvement actions is placed (Table 1). Similarly, the organizational scorecard contains these all issues (Table 2). 
Table 1. Proposed performance measurement framework/personal scorecards

\begin{tabular}{|c|c|c|c|c|c|c|}
\hline $\begin{array}{l}\text { Performance } \\
\text { Perspectives }\end{array}$ & $\begin{array}{l}\text { Personal } \\
\text { Goals }\end{array}$ & $\begin{array}{l}\text { Personal } \\
\text { Objectives }\end{array}$ & $\begin{array}{c}\text { Personal } \\
\text { Performance } \\
\text { Indicators (KPIs) }\end{array}$ & $\begin{array}{c}\text { Personal Performance } \\
\text { Measures }\end{array}$ & $\begin{array}{l}\text { Personal } \\
\text { Performance } \\
\text { Targets }\end{array}$ & $\begin{array}{c}\text { Pers. } \\
\text { Perform. } \\
\text { Improvement } \\
\text { Actions } \\
\end{array}$ \\
\hline \multirow{5}{*}{ Financial } & \multirow{5}{*}{$\begin{array}{l}\text { Financial } \\
\text { health or } \\
\text { stability }\end{array}$} & \multirow{2}{*}{$\begin{array}{l}\text { More income or } \\
\text { increase salary }\end{array}$} & Salary & $\begin{array}{c}\text { Annual salary } \\
\text { percentage growth }\end{array}$ & & \\
\hline & & & Incentives & Annual \% growth & & \\
\hline & & Safer income & Pension & $\%$ of gross salary & & \\
\hline & & & Insurance & \% of gross salary & & \\
\hline & & Expenses control & $\begin{array}{c}\text { \% of the income } \\
\text { destined to } \\
\text { expense }\end{array}$ & $\begin{array}{c}\text { \% growth in a period of } \\
\text { time }\end{array}$ & & \\
\hline \multirow{5}{*}{$\begin{array}{l}\text { Customer } \\
\text { (external) }\end{array}$} & \multirow{2}{*}{$\begin{array}{l}\text { To have good } \\
\text { relationship } \\
\text { and be } \\
\text { appreciated by } \\
\text { families, } \\
\text { colleagues, } \\
\text { friends and } \\
\text { the employer }\end{array}$} & $\begin{array}{l}\text { To be appreciated } \\
\text { by spouse }\end{array}$ & $\begin{array}{c}\text { frequency } \\
\text { you went out } \\
\text { together in a good } \\
\text { place }\end{array}$ & $\begin{array}{l}\text { No. of meetings/time } \\
\text { period }\end{array}$ & & \\
\hline & & $\begin{array}{l}\text { To be appreciated } \\
\text { by friends }\end{array}$ & true friends & $\begin{array}{l}\text { Number of honest } \\
\text { friends }\end{array}$ & & \\
\hline & \multirow{3}{*}{$\begin{array}{l}\text { To provide } \\
\text { high } \\
\text { quality work }\end{array}$} & $\begin{array}{l}\text { To be appreciated } \\
\text { by the employer }\end{array}$ & $\begin{array}{l}\text { Level of the } \\
\text { received } \\
\text { Reward } \\
\end{array}$ & $\begin{array}{l}\text { Type and number of } \\
\text { reward }\end{array}$ & & \\
\hline & & $\begin{array}{c}\text { To improve } \\
\text { employees' } \\
\text { satisfaction level }\end{array}$ & $\begin{array}{c}\text { Employees’ } \\
\text { satisfaction level }\end{array}$ & $\begin{array}{l}\text { \% of employees’ } \\
\text { satisfaction level }\end{array}$ & & \\
\hline & & $\begin{array}{l}\text { To build trust } \\
\text { from the employer } \\
\text { while doing } \\
\text { my work }\end{array}$ & $\begin{array}{c}\text { The employer's } \\
\text { level of } \\
\text { satisfaction }\end{array}$ & $\begin{array}{l}\text { \% of employer's } \\
\text { level of satisfaction }\end{array}$ & & \\
\hline \multirow{5}{*}{$\begin{array}{l}\text { Internal } \\
\text { personal } \\
\text { Process }\end{array}$} & \multirow{5}{*}{$\begin{array}{l}\text { To fight for } \\
\text { physical and } \\
\text { psychical } \\
\text { health } \\
\text { (physical } \\
\text { health \& } \\
\text { mental state) }\end{array}$} & \multirow{3}{*}{$\begin{array}{l}\text { To be in a good } \\
\text { position in both } \\
\text { physically and } \\
\text { psychically }\end{array}$} & Sick leave & $\%$ of sick leave & & \\
\hline & & & Pressure level & Level of pressure & & \\
\hline & & & $\begin{array}{c}\text { Level of Immunity } \\
\text { under stress } \\
\text { conditions } \\
\end{array}$ & Immunity level & & \\
\hline & & $\begin{array}{c}\text { To get more spare } \\
\text { time }\end{array}$ & Spare time & $\begin{array}{c}\text { The number of holidays } \\
\text { paid per year }\end{array}$ & & \\
\hline & & $\begin{array}{c}\text { To enjoy good } \\
\text { thinks in life } \\
\end{array}$ & Pleasure & Happiness level & & \\
\hline \multirow{6}{*}{$\begin{array}{l}\text { Knowledge } \\
\text { \& Learning }\end{array}$} & \multirow{2}{*}{$\begin{array}{l}\text { To have } \\
\text { motivation to } \\
\text { learn from } \\
\text { somebody } \\
\text { mistakes, to } \\
\text { improve } \\
\text { myself and to } \\
\text { develop } \\
\text { myself } \\
\text { continuously }\end{array}$} & $\begin{array}{c}\text { To increase work } \\
\text { Productivity } \\
\end{array}$ & Work productivity & Personal outputs/inputs & & \\
\hline & & $\begin{array}{l}\text { To improved } \\
\text { management } \\
\text { competences }\end{array}$ & Initiatives & $\begin{array}{l}\text { Number of efficient } \\
\text { Initiatives }\end{array}$ & & \\
\hline & \multirow{4}{*}{$\begin{array}{l}\text { To learn every } \\
\text { day }\end{array}$} & \multirow{2}{*}{$\begin{array}{l}\text { Self- development } \\
\text { opportunity in the } \\
\text { field of } \\
\text { management }\end{array}$} & Strategic proposals & $\begin{array}{c}\text { \# of successful } \\
\text { proposals with strategic } \\
\text { improvements } \\
\end{array}$ & & \\
\hline & & & $\begin{array}{l}\text { management } \\
\text { competences }\end{array}$ & $\begin{array}{c}\text { percentage of available } \\
\text { management } \\
\text { competences }\end{array}$ & & \\
\hline & & \multirow{2}{*}{$\begin{array}{l}\text { Leadership } \\
\text { abilities } \\
\text { Improvement }\end{array}$} & $\begin{array}{c}\text { Attended } \\
\text { management } \\
\text { trainings } \\
\end{array}$ & $\begin{array}{c}\text { \# of attended } \\
\text { management trainings }\end{array}$ & & \\
\hline & & & $\begin{array}{l}\text { Employees feeling } \\
\text { in the leadership }\end{array}$ & $\begin{array}{c}\text { \% of employees feeling } \\
\text { they are working under } \\
\text { an efficient leadership }\end{array}$ & & \\
\hline
\end{tabular}


Table 2. Proposed performance measurement framework /organizational scorecard

\begin{tabular}{|c|c|c|c|c|c|c|}
\hline $\begin{array}{l}\text { Performance } \\
\text { Perspectives }\end{array}$ & $\begin{array}{c}\text { Organizational } \\
\text { Goals }\end{array}$ & $\begin{array}{c}\text { Org. } \\
\text { Performance } \\
\text { Indicators } \\
\end{array}$ & $\begin{array}{l}\text { Organizational } \\
\text { objectives }\end{array}$ & $\begin{array}{c}\text { Org. } \\
\text { performance } \\
\text { Measures } \\
\end{array}$ & $\begin{array}{c}\text { Org. } \\
\text { Performance } \\
\text { Targets } \\
\end{array}$ & $\begin{array}{c}\text { Org. Perf. } \\
\text { Improvement } \\
\text { Actions } \\
\end{array}$ \\
\hline \multirow{3}{*}{ Customer } & \multirow{3}{*}{$\begin{array}{l}\text { Continuously } \\
\text { improve } \\
\text { customer } \\
\text { satisfaction }\end{array}$} & Delivery & $\begin{array}{c}\text { Increase on time } \\
\text { delivery }\end{array}$ & $\begin{array}{c}\% \text { of deliveries } \\
\text { on time }\end{array}$ & & \\
\hline & & $\begin{array}{c}\text { Customer } \\
\text { satisfaction }\end{array}$ & $\begin{array}{l}\text { Satisfying } \\
\text { customers }\end{array}$ & \# of complaints & & \\
\hline & & Price & Competitive price & $\begin{array}{l}\text { Competitive } \\
\text { comparison }\end{array}$ & & \\
\hline \multirow{5}{*}{$\begin{array}{l}\text { Internal } \\
\text { Business } \\
\text { Process }\end{array}$} & \multirow{5}{*}{$\begin{array}{l}\text { Continuously } \\
\text { improve } \\
\text { business } \\
\text { processes }\end{array}$} & Cycle time & $\begin{array}{l}\text { Reduce product } \\
\text { cycle time }\end{array}$ & $\begin{array}{c}\text { Average cycle } \\
\text { time }\end{array}$ & & \\
\hline & & $\begin{array}{c}\text { Labor } \\
\text { productivity }\end{array}$ & $\begin{array}{c}\text { Increase } \\
\text { productivity }\end{array}$ & $\begin{array}{l}\text { Average O/P per } \\
\text { employee }\end{array}$ & & \\
\hline & & Quality & $\begin{array}{l}\text { Produce defect free } \\
\text { product }\end{array}$ & $\begin{array}{c}\text { \# of defects \& \# } \\
\text { of items } \\
\text { reworked }\end{array}$ & & \\
\hline & & $\begin{array}{c}\text { Material } \\
\text { utilization }\end{array}$ & $\begin{array}{c}\text { Increase material } \\
\text { utilization }\end{array}$ & Percentage & & \\
\hline & & $\begin{array}{c}\text { Capacity } \\
\text { utilization }\end{array}$ & $\begin{array}{c}\text { Increase capacity } \\
\text { utilization }\end{array}$ & Percentage & & \\
\hline \multirow{4}{*}{$\begin{array}{l}\text { Innovation } \\
\text { and Growth }\end{array}$} & \multirow{4}{*}{$\begin{array}{c}\text { Continuously } \\
\text { develop and } \\
\text { deliver new } \\
\text { innovative } \\
\text { products \& } \\
\text { services }\end{array}$} & R \& D & $\begin{array}{c}\text { Enhance R\&D } \\
\text { activities }\end{array}$ & $\begin{array}{c}\text { \# of new } \\
\text { products/services }\end{array}$ & & \\
\hline & & Modularization & $\begin{array}{c}\text { Improve } \\
\text { interchangeability } \\
\text { of shoe parts }\end{array}$ & \# of reused parts & & \\
\hline & & \multirow{2}{*}{$\begin{array}{l}\text { Training \& } \\
\text { education }\end{array}$} & $\begin{array}{l}\text { Improve employee } \\
\text { skill }\end{array}$ & Skill level & & \\
\hline & & & $\begin{array}{l}\text { Improve employee } \\
\text { qualification status }\end{array}$ & $\begin{array}{l}\text { Qualification } \\
\text { growth }\end{array}$ & & \\
\hline \multirow{4}{*}{ Financial } & \multirow{4}{*}{$\begin{array}{l}\text { Continuously } \\
\text { improve } \\
\text { financial } \\
\text { performance }\end{array}$} & Sales growth & Increase revenue & $\begin{array}{c}\text { Growth rate in } \\
\text { sales }\end{array}$ & & \\
\hline & & Market share & $\begin{array}{c}\text { Increase market } \\
\text { share }\end{array}$ & $\begin{array}{c}\text { Company’s } \\
\text { share } \\
\end{array}$ & & \\
\hline & & $\begin{array}{c}\text { Cost of goods } \\
\text { sold }\end{array}$ & $\begin{array}{c}\text { Reduce } \\
\text { cost/expense }\end{array}$ & $\begin{array}{c}\text { Average unit } \\
\text { cost }\end{array}$ & & \\
\hline & & Profitability/ROI & $\begin{array}{l}\text { Increase return on } \\
\text { investment }\end{array}$ & ROI or ROA & & \\
\hline
\end{tabular}

\subsection{Development of Implementation Guideline for the Proposed Method}

The guideline developed describes how to start a TPS program and bring it to a state where the process of continuous improvement is institutionalized in the shoe factory. Primarily the implementation of TPS to any organization is not an easy task because it requires investment, patience, organization wide commitment etc. It is not a program that is applied and leaves it rather it requires continuous improvement. Since organizations differ in their orientation, the application of one canned TPS system will not generally provide the expected results of the cultural change to others. Seven general steps are developed here to be applied to the footwear company and this is done based on TPS concept and TQM implementation concept (Fig. 2).

The first three steps are considerations and activities to be taken by the shoe company before the application of TPS concept. For the successful implementation of TPS concepts, a guide called TPS cycle has been developed. This TPS cyclic model consists of the remaining four steps of the implementation guide line.
Step 1:

Need for TPS \& Management Commitment

Step 2:

Company Wide Awareness

Step 3:

TPS Team Formation

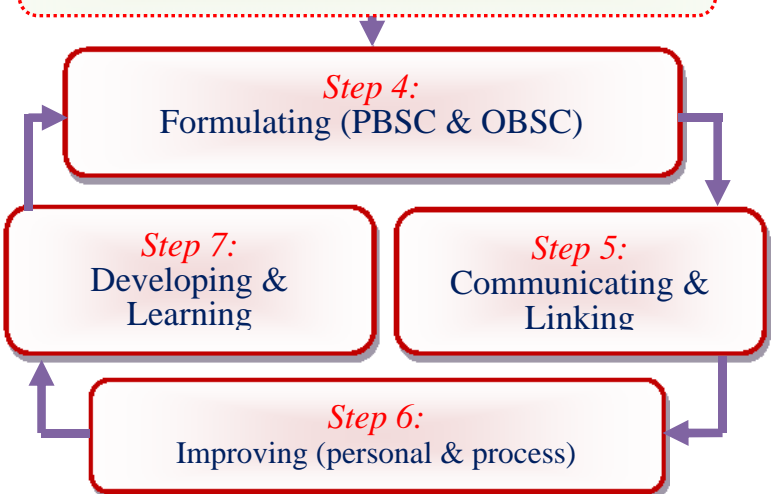

Fig. 2. Proposed implementation steps of TPS 


\section{Conclusion and Recommendation}

From the study, it is concluded that the performance of Ethiopian Leather Footwear Industry is not satisfactory and the performance measurement and improvement methods practiced are not effective mainly due to the methods' limitation on total performance aspects, measurement frameworks and implementation guidelines. Moreover, most existing methods are not well committed to learning and limited in considering personal ambitions of employees and as a result they could not sufficiently improve the total performance of organizations. It is because if a worker personal ambition is related with the organization's objective, then he/she will be committed and work with similar direction to reach the company's shared purpose or objective. With this argument, the researcher believes that the newly introduced performance measurement and improvement method, Total performance scorecard, will be a better method for Ethiopian LFI to bring a total company-wide performance improvement and competitiveness.

The proposed personal scorecard using plan, do, act and challenge cycle (PDAC) has to be implemented to all Ethiopian shoe factories because the labor productivity problem is available in the national level and only trainings (short term or long term) could not bring satisfactory labor productivity improvement. However, it is believed that in addition to the on-job trainings, there has to be a mental setup change within employee and this can be achieved through proper implementation and use of PDAC method within the proposed personal scorecard.

As a recommendation, firstly, though the shoe factories have both internal and external or sector level problems they have to give more emphasis to the internal or firm level problems, where it can be addressed using only their individual potentials and resources with the appropriate improvement method. Therefore, the case company is highly recommended to implement the proposed method with the developed performance measurement framework and implementation guideline so as to solve the identified problems and bring total company performance improvement and competitiveness. Secondly, the export led strategy of Ethiopian government is better means for developing competitiveness of Ethiopian leather footwear factories (ELFFs) internationally due to the technology transfer (knowledge, new designs, techniques and methods while bringing their design) in between local firms and foreign customers. So in this paper, it is highly recommended that ELFFs has to work more on it because export strategy will drive the local one. Finally, to solve the external problems, it is highly recommended that ELFFs have to work in collaboration with stakeholders of the subsector; primarily with the government of Ethiopia (under MoI and LIDI) and other parties such as ELIA, UNIDO, GTZ, EQA, COMESA and ecpp.

\section{Future Research}

Many shoe companies are not achieving a corresponding improvement in their business performance due to a failure to address the whole spectrum of their supply chain. As TPS is firm level tool which can rarely solve external factors, a better supply chain network is necessary. Accordingly, "supply chain performance improvement" is suggested future research area to enhance the performance of Ethiopian shoe factories.

\section{References}

Askin, R G and Standridge, C. R. (1993). Modeling Analysis of Manufacturing System, 123, New York, Wiley.

Beyene, T. D., Gebeyehu, S. G., and Mengistu, A. T. (2018). Application of Failure Mode Effect Analysis (FMEA) to Reduce Downtime in a Textile Share Company. Journal of Engineering, Project, and Production Management, 8(1), 40-46.

Brown, A. W. (2006). Review of Performance Improvement Models and Tools, IDeA and Audit Commission PMMI team, Principal Consultant, IDeA, 6-7.

Cherkos, T., Zegeye, M., Tilahun, S., and Avvari, M. (2017). Examining significant factors in micro and small enterprises performance: case study in Amhara region, Ethiopia. Journal of Industrial Engineering International, 14(2), 227-239.

Daniels, S. (1997). Back to basics with productivity techniques. Work study, 46(2), 52-57.

Enos, D. D. (2000). Performance Improvement: Making It Happen. Book review, St. Lucie Press.

Embassy of Japan in Ethiopia (2008). A Series of Studies on Industries in Ethiopia.

Global Development Solutions (2006). Value chain analysis for the skins and leather sector in Ethiopia. Unpublished Report.

Gruenberg T. (2004). Performance Improvement: Towards a method for finding and prioritizing potential performance improvement areas in manufacturing operations. International Journal of Productivity and Performance Management, 53(1), 52-71.

Gruenberg T. (2007). Performance Improvement -A Method to Support Performance Improvement in Industrial Operations. A doctorial thesis, Stockholm.

Kanthi M. N. M. (2006). System Level Effectiveness Metrics for Performance Monitoring and Diagnostics. PhD thesis, University of Cincinnati.

Kassaneh, T. C. (2011). Performance Analysis and Improvement of Ethiopia Leather and Footware Factories. Master Thesis, Addis Ababa University, Ethiopia.

Kassaneh, T. C and Havinal V. (2017). Investigation of Company-wide Performance Factors in Ethiopian Leather Footwear Industry. Research Journal of Social Science and Management, 7(6).

Madalina, B. (2008). The Application of the Total Performance Scorecard (TPS) Process in the Sales Management. Annals of the University of Oradea, Economic Science Series, 17(4).

Performance-Based Management Special Interest Group (2001). Establishing an Integrated Performance Measurement System - The Performance-Based Management Handbook, Volume 2. Available at: http://www.orau.gov/pbm.

Rampersad, H. K. (2003). Total Performance Scorecard: Redefining Management to Achieve Performance with Integrity. Butterworth-Heinemann Business Books: Oxford.

Rampersad, H. K. (2005). Total Performance Scorecard: Aligning Human Capital with Business Strategy and Ethics. Nanyang Business Review, 4(1), 71-99.

Rampersad, H. K. (2007). Total Performance Scorecard; a new blueprint for sustained organizational performance with Integrity, California. 
Sonobe, T., Akoten, J. E., and Otsuka, K. (2009). An Exploration into the Successful Development of the Leather-Shoe Industry in Ethiopia. Review of Development Economics, 13(4), 719-736.

Sunil K. and Rachita G. (2010). Measuring efficiency, effectiveness and performance of Indian public sector banks. International Journal of Productivity and Performance Management, 59 (1), 51-74.

Sutton, J. and Kellow, N. (2010). An Enterprise Map of Ethiopia. International Growth Centre.

UNIDO (2005). A Master Plan for the Ethiopian Leather and Leather Products Industry (LLPI).

Wongrassamee, S., Gardiner, P. D., and Simmons J. E. L. (2003). Performance measurement tools: the balanced scorecard and the EFQM excellence model, Measuring Business excellence, 7(1),14-29.

XYZ Company (2009). Benchmark Implementation Plan for the Ethiopian Footwear Sector (Pilot Project on XYZ Company and ABC Shoe Factory), Ethiopia.

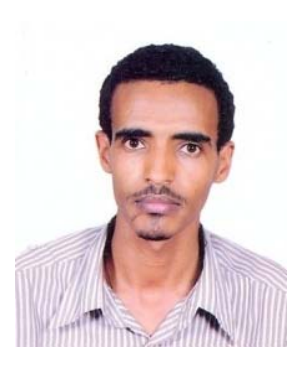

Tomas Cherkos Kassaneh: BSc in Industrial Engineering, MSc in Industrial Engineering. Currently, Lecturer and Researcher, Bahir Dar Institute of Technology, Bahir Dar University, Ethiopia. Have three articles and one eBook published; participated in two international conferences.

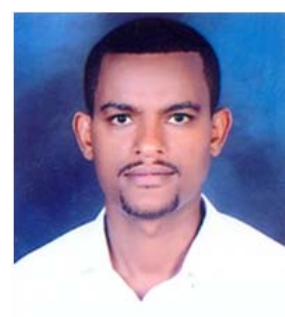

Robel Negussie Workalemahu: B.Sc in Industrial Egineering, M.Sc in Mechanical Engineering (Industrial Engineering), Currently Lecturer, Faculty of Mechanical and Industrial Engineering, Bahir Dar Institute of Technology, Bahir Dar University, Bahir Dar, Ethiopia. 